\title{
The Application of Multimedia and Network Technology in Music Teaching of Art Colleges
}

\author{
Xiangdong Tan \\ Chongqing Vocational College Of Culture And Arts, 400067, China \\ xiangdong@163.com
}

Keywords: web course; fire; art colleges; music education; application.

\begin{abstract}
This paper take a network sampling investigation partial provinces the higher normal universities music network curriculum construction and the use present situation, discovered that the existence the question, like the course content is unitary, the teaching method is obsolete, the teaching design lacks interactive, the appraisal mechanism not perfect as well as the guidance system not clear and so on questions, the author reflected in view of the investigation bureau the prominent question, carried on has combed with analyzes, and proposed several suggestions, how to did solve enable the network curriculum to obtain the reasonable application and the promotion in the high music education, It has a practical significance to enhanced the high music education the quality, to promote higher normal universities music network curriculum constructs, trains high quality personnel.
\end{abstract}

\section{Introduction}

Along with the world science technology and economic globalization's fast development, the contemporary society has a higher request to talented person's raise. Since the new century, human-oriented mode of thinking was broken; the scientists step into the world of arts bravely, arts educator has also picked up the scientific instrument. Computer science has entered into the music halls that the typical sense of the world, classroom music teaching is integrating with web-based course and developing rapidly. Our country ordinary higher normal universities' educational technique modernization level also promotes rapidly, many schools response National Education Policy proposed the informatization teaching's policy, enlarges dynamics investment network high-quality goods curriculum the construction, realizes the classroom instruction and the network teaching diligently unifies. However, in the higher normal universities which equipped with computer and various types of sky networks, the network of music curriculum construction is very difficult, this is opposed to Humanities development of higher Normal Universities.

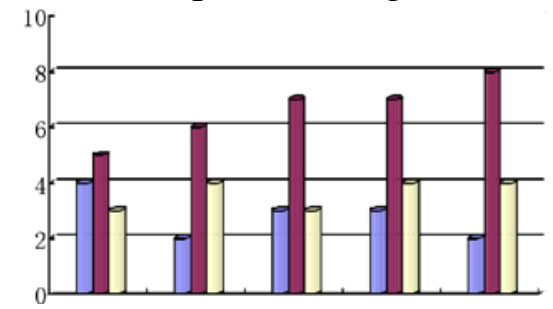

Fig. 1 Network course statistics

The higher normal universities are the basement of transport the qualified music teachers for various elementary and middle schools, are the growth and progress cradle of elementary and middle schools. Along with various universities increased enrolment population's unceasing increase, with enhances unceasingly to the corresponding software and hardware facilities request, applies the network curriculum in the normal universities' music education can solve this question .Therefore, the application of web-based course in music education of normal university is in the need of improvement and perfection. Music network curriculum is the form of taking the network as the main music teaching carrier, through provides kinds of rich multimedia study resources, the 
multi-dimensional exchange platform and the nimble study way to promote the learner's study fully, plays teacher's guidance role fully, manifests student's main body status. The student may act according to the actual situation, arranges the learning program under teacher's instruction, to grasp the study progress, the inspection study effect, enables student's initiative, the enthusiasm to obtain the display, creation ability and exploration ability obtains the raise. However, the highly effective appraisal system and the management system management system provide an important guarantee for applying his network curriculum in the higher music education.

\section{The Theoretical Basis of the Application of Multimedia Network Course in Music Education}

With the development of multimedia technology and network technology, network multimedia technology teaching has become an inevitable trend. The emergence of multimedia technology and the popularization and application in teaching have led to a new leap in educational technology and educational method. Especially with the constant development and progress of compression coding technology of voice, data, video and network transmission technology, through network transmission, people can release and access to remote video, audio, data information, obtain educational resources anytime and anywhere. Network multimedia teaching can be really realized by network studying. The progress of network multimedia teaching technology and the emergence of network multimedia teaching can take abundant computer graphics, text and voice information into daily teaching, make full use of and share teaching resources. They provide scientific, effective ways and means for the continuous exploration in the quality education and lightening work, and make a solid step for our country to realize the strategy of rejuvenating the country through science and education.

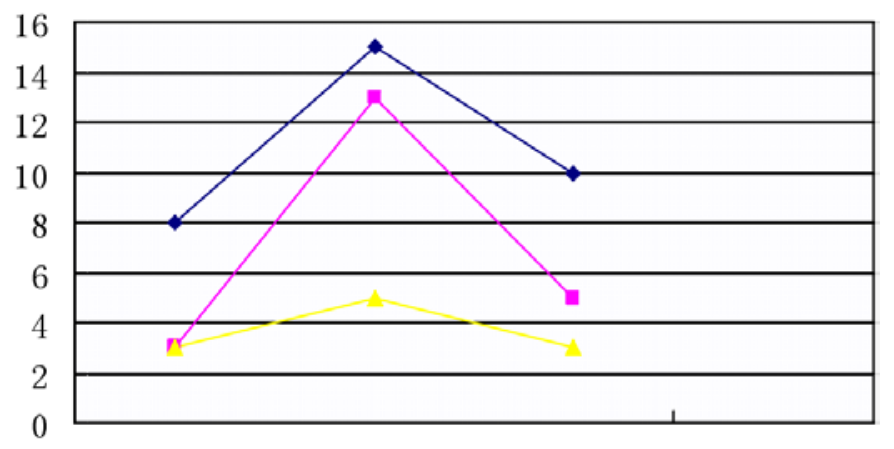

Fig. 2 Music Course Level

This thesis studies the environment construction of network multimedia teaching and the design of teaching courseware, expounds the background and significance of the study, the domestic and overseas current situation and developmental trend, and briefly explains the study's content and objective. According to the in depth research and social practice, the thesis deeply researches the design implementation of the network multimedia teaching system and the courseware's design implementation. Based on the research, it designs and explores network multimedia teaching courseware management system. The system's design and exploitation start from the demand analysis of the network multimedia teaching courseware management system, including the demand of network multimedia teaching environment, the analysis of the functional demand and the work process, based on the demand analysis, it designs and explores network multimedia teaching courseware management system. It includes four parts: the form of system module, the module design of the network multimedia teaching management system, the design of streaming media courseware on demand system and the database design of the network multimedia courseware.

According to the design's thought, it studies the specific implementation the network multimedia teaching courseware management system. The system implementation includes the system module, the design of the teaching module and the design of the database access. In order to detect whether the system can run, the related function can reach the teaching requirements, we test the system in the end. 
The system test includes two parts: one is the analysis of the system test environment; the other is the test of the system login interface and the system's function.

\section{Results and discussion}

As the world entering into the era of knowledge economy which take digital and information as typical characteristics, the scientific and technological revolution not only provides important opportunities for the social changes and technological development of China, but also starts an irresistible challenge for China's education. Multimedia and network technology are gradually applied to institutions of higher learning in all disciplines of teaching. Developing modern educational technology has become an inevitable choice for the tide of history.

The paper proposes five points as the basis of the application of web-based course in music education of normal university, such as "Constructivism Theory", "Humanism theory", "the basic principles of music pedagogy", "Music Education in the spirit of the document"," Education and dissemination of theoretical study".

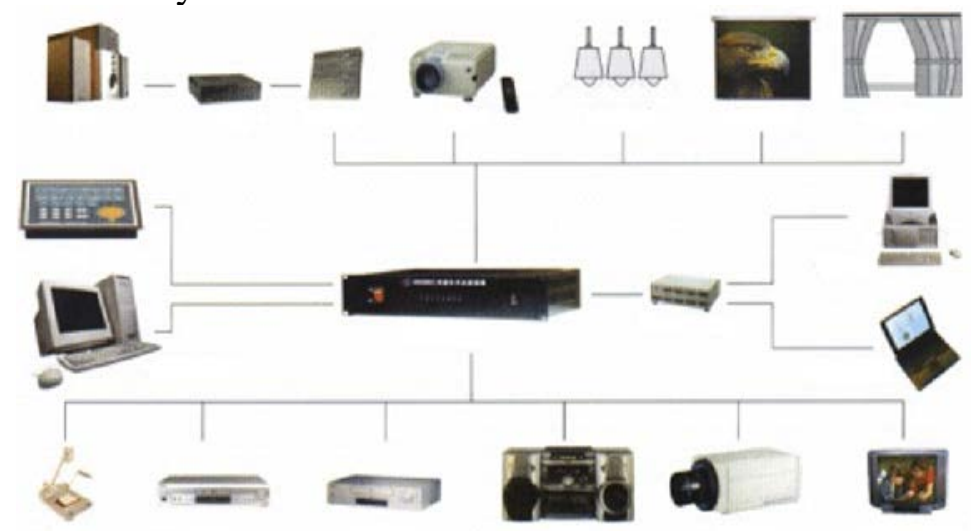

Fig. 3 Single multimedia classroom equipment connection diagram

Expatiates the Principles of the application of web-based course in music education of teachers' college, include "course content should be rich and intuitive", "teaching methods should be full of autonomy and creativity", "the teaching process should be full of interactive and collaborative", "instructional design guidance should be guiding and initiative", "teaching media should be full of scientific and ordering". Web-based course of music is rich in resources, user-friendly, intuitive and self-image and interactive help, this is useful to embody the characteristics of music, improving teaching effectiveness, and promote music education and teaching development.

The author combined with training objectives and the nature of music education of China's Normal University, proposes five Suggestions and tentative plans that from the teachers, educational philosophy, curriculum resources, the evaluation mechanism and the teaching environment to the application of web-based course in music education of normal university. It is in order to prominent the web-based course characteristic and Music Feature.

Firstly, the paper quoted the relevant educational technology theory, defined the concepts of multimedia and network technology. It selected two universities in southern China as study samples in accordance with the current reality. Secondly, through the analysis of feasibility and necessity, the paper pointed out that introduction of mufti-media and network technologies to the teaching in universities is reasonable. Thirdly, through empirical research, the paper selected Jinan University and the Faculty of Business of Guangzhou as special cases. Basing on investigation and study, we analysed the practice of mufti-media and network technologies in teaching in recent years. At last, we analysed the existing problems of multimedia and network technology teaching, and put forward our views and suggestions. 


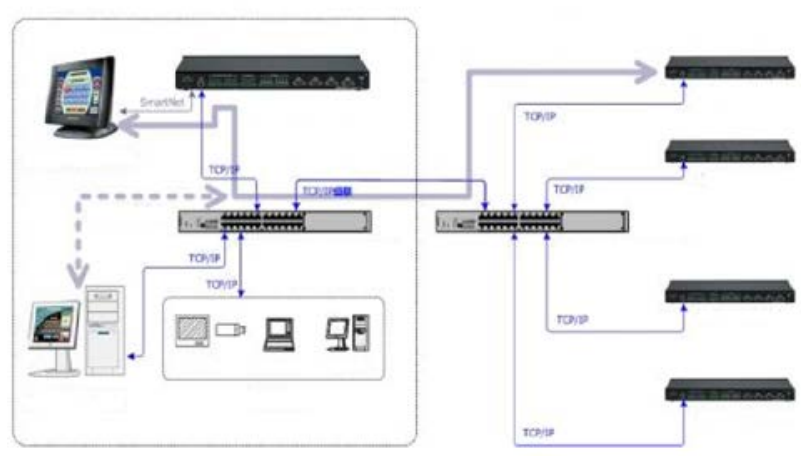

Fig. 4 Network multimedia teaching system diagram

The innovation of the paper are as follow: firstly, multimedia and network technology teaching should base on the reality of Jinan university, Establish a reasonable courseware and embody the characteristics of universities, Secondly, universities should attach importance to the development and effective integration of network resources, use the advantages of multimedia courseware network to strengthen the cultivation of innovative students. At last, universities should establish a corresponding mechanism for encouraging teachers to enable outstanding multimedia courseware production. The welfare, salaries and titles of teachers should link to the results of the production. In this way, universities could inspire the enthusiasm of teachers and ensure the quality of software.

\section{Conclusion}

In music teaching of higher art colleges and universities, the application of multimedia technology can create. vivid, image teaching atmosphere, relaxed environment, which can not only promote students' learning efficiency, but also obviously improve the students level of music appreciation. Firstly the author analyzes the present situation of the application of multimedia technology in music teaching in higher vocational colleges and universities and multimedia technology in music teaching effects, and then she further discusses the practical application of multimedia technology in music teaching, hoping to contribute to the improvement of higher vocational college music teaching level.

\section{References}

[1] JIN Cheng-xing, LI Xin-guo. Research on the Application of Multimedia-and-Network-based College English Teaching Mode-A Case Study in Anhui University of Technology and Science[J]. Computer-Assisted Foreign Language Education in China, 2010, 20(12), pp. 65-70.

[2] Zhang Z. The Application of Multimedia and Network Technologies in College Piano Teaching[C]// 2016 international conference on contemporary education, social sciences and humanities. 2016, pp. 1406-1425.

[3] Suo X M. Exploring the Application of Multimedia Resource Center and Network Technology in Teaching in Ethnic Universities and Colleges[J]. Ethnic Education Study, 2003, (2), pp. 89-106.

[4] Yingjun L I. A Probe into the Application of the Multimedia and Network Technology to College English Teaching[J]. Journal of Xinjiang Normal University, 2006, 15(12), pp. 274-78. 